\title{
CONSERVATION AND REINTRODUCTION OF NATIVE ORCHIDS OF SINGAPORE - THE NEXT PHASE
}

\author{
TIM W. YAM ${ }^{1}$, FELICIA TAY, PETER ANG, and WEIJING SOH \\ ${ }^{1}$ Singapore Botanic Gardens, 1 Cluny Road, Singapore Botanic Gardens, Singapore 259569, YAM_Tim_Wing@nparks.gov.sg. \\ Tel.: (65) 64717332; Fax: (65) 64674832
}

\section{ABSTRACT}

Some 226 species of native orchids have been recorded in Singapore. However, of these 178 are considered to be extinct, and only five are common. The orchid conservation programme aims to monitor existing species, explore ways to conserve their germplasm, and increase their number for subsequent re-introduction into appropriate habitats, including roadside trees, parks and nature areas. From 1999 to 2008, we carried out experiments and have successfully propagated and re-introduced 5 species of native orchids, namely Grammatophyllum speciosum Blume, Bulbophyllum vaginatum Rchb.f., Bulbophyllum membranaceum Teijsm. and Binn., Cymbidium finlaysonianum Lindl. and Cymbidium bicolor Lindl. spp. pubescens (Lindl.) Du Puy and Cribb. More than $80 \%$ of the plants are growing well and all that have survived have flowered. From 2009 to 2012, we expanded our reintroduction efforts by planting fifteen species: Bulbophyllum blumei (Lindl.) J.J.Sm., Bulbophyllum medusae (Lindl.) Rchb.f., Bulbophyllum membranaceum Teijsm. and Binn., Bulbophyllum purpurascens (T. and B.) J.J.Sm., Bulbophyllum vaginatum Rchb.f., Coelogyne mayeriana Rchb.f., Coelogyne rochussenii De Vr., Cymbidium finlaysonianum Lindl., Dendrobium aloifolium (Blume) Rchb.f., Dendrobium leonis (Lindl.) Rchb.f., Grammatophyllum speciosum Blume, Phalaenopsis cornu cervi (Breda) Bl. and Rchb.f., Cymbidium bicolor Lindl. spp. pubescens (Lindl.) Du Puy and Cribb, Thrixspermum amplexicaule Rchb.f., and Vanilla griffithii Rchb.f. is scheduled to be planted. One of our goals is that the reintroduced species would act as catalysts for the restoration of at least part of the original ecosystem. For example, pollinators may be attracted to sites where orchids have been re-introduced. Subsequently, orchid seeds that are produced from naturally pollinated flowers may be blown to the safe sites where appropriate mycorrhizal fungi are present; thus making germination and subsequent establishment of natural populations in areas beyond those in which the re-introductions occurred!

Keywords: conservation, native, orchids, Singapore, re-introduction

\section{Introduction}

The Republic of Singapore is a city-state located off the southern tip of the Malay Peninsula, between the South China Sea and the Indian Ocean, 137 kilometres or about $1^{\circ}$ north of the equator. Singapore consists of the main island and 62 nearby islands. The total land area is about $710 \mathrm{~km}^{2}$ and about $23 \%$ of Singapore's land area consists of forest and nature reserves. The only significant primary rainforest is the Bukit Timah Nature Reserve. The country has a tropical rainforest climate with no distinctive seasons, uniform temperature throughout the year, high relative humidity, and abundant rainfall. Tempera- tures range from 22 to $34^{\circ} \mathrm{C}$. Relative humidity averages around $90 \%$ in the morning and $60 \%$ in the afternoon, and can reach $100 \%$ during prolonged heavy rain. Annual rainfall is about $2300 \mathrm{~mm}$; the wettest months are from November to January (Table 1). Although Singapore is a modern city, it had many interesting types of natural habitats. In the heart of the main island there is a primary rainforest and freshwater swamp forest. In addition, some mangroves also remain. The other habitats consist of secondary forests, shrub, grasslands and urban parks and fields.

Numerous ecological niches combined with appropriate climatic conditions account for the large number of orchid

Table 1 Climate data for Singapore. ${ }^{1}$

\begin{tabular}{|c|c|c|c|c|c|c|c|c|c|c|c|c|c|}
\hline Month & Jan & Feb & Mar & Apr & May & Jun & Jul & Aug & Sep & Oct & Nov & Dec & Year \\
\hline $\begin{array}{l}\text { Average } \\
\text { high }{ }^{\circ} \mathrm{C}\left({ }^{\circ} \mathrm{F}\right)\end{array}$ & $\begin{array}{c}30.1 \\
(86.2)\end{array}$ & $\begin{array}{l}31.1 \\
(88)\end{array}$ & $\begin{array}{c}31.6 \\
(88.9)\end{array}$ & $\begin{array}{c}31.7 \\
(89.1)\end{array}$ & $\begin{array}{c}31.6 \\
(88.9)\end{array}$ & $\begin{array}{c}31.3 \\
(88.3)\end{array}$ & $\begin{array}{c}30.9 \\
(87.6)\end{array}$ & $\begin{array}{c}30.9 \\
(87.6)\end{array}$ & $\begin{array}{c}30.9 \\
(87.6)\end{array}$ & $\begin{array}{l}31.1 \\
(88)\end{array}$ & $\begin{array}{c}30.6 \\
(87.1)\end{array}$ & $\begin{array}{c}29.9 \\
(85.8)\end{array}$ & $\begin{array}{c}31.0 \\
(87.8)\end{array}$ \\
\hline $\begin{array}{l}\text { Average } \\
\text { low }{ }^{\circ} \mathrm{C}\left({ }^{\circ} \mathrm{F}\right)\end{array}$ & $\begin{array}{c}23.3 \\
(73.9)\end{array}$ & $\begin{array}{c}23.6 \\
(74.5)\end{array}$ & $\begin{array}{l}23.9 \\
(75)\end{array}$ & $\begin{array}{c}24.4 \\
(75.9)\end{array}$ & $\begin{array}{c}24.8 \\
(76.6)\end{array}$ & $\begin{array}{c}24.7 \\
(76.5)\end{array}$ & $\begin{array}{l}24.5 \\
(76.1)\end{array}$ & $\begin{array}{c}24.4 \\
(75.9)\end{array}$ & $\begin{array}{c}24.2 \\
(75.6)\end{array}$ & $\begin{array}{c}24.0 \\
(75.2)\end{array}$ & $\begin{array}{c}23.7 \\
(74.7)\end{array}$ & $\begin{array}{c}23.4 \\
(74.1)\end{array}$ & $\begin{array}{c}24.1 \\
(75.4)\end{array}$ \\
\hline $\begin{array}{l}\text { Rainfall mm } \\
\text { (inches) }\end{array}$ & $\begin{array}{c}242.5 \\
(9.547) \\
\end{array}$ & $\begin{array}{c}162.0 \\
(6.378) \\
\end{array}$ & $\begin{array}{c}184.8 \\
(7.276) \\
\end{array}$ & $\begin{array}{c}178.8 \\
(7.039) \\
\end{array}$ & $\begin{array}{c}171.8 \\
(6.764) \\
\end{array}$ & $\begin{array}{c}161.2 \\
(6.346) \\
\end{array}$ & $\begin{array}{c}158.3 \\
(6.232) \\
\end{array}$ & $\begin{array}{c}176.2 \\
(6.937) \\
\end{array}$ & $\begin{array}{c}169.7 \\
(6.681) \\
\end{array}$ & $\begin{array}{r}193.9 \\
(7.634) \\
\end{array}$ & $\begin{array}{c}255.7 \\
(10.067) \\
\end{array}$ & $\begin{array}{c}288.2 \\
(11.346) \\
\end{array}$ & $\begin{array}{l}2,343.1 \\
(92.248) \\
\end{array}$ \\
\hline $\begin{array}{l}\text { Average } \\
\text { rainy days }\end{array}$ & 15 & 11 & 14 & 15 & 14 & 13 & 13 & 14 & 14 & 16 & 19 & 19 & 177 \\
\hline $\begin{array}{l}\text { Sunshine } \\
\text { hours }\end{array}$ & 173.6 & 183.6 & 192.2 & 174.0 & 179.8 & 177.0 & 189.1 & 179.8 & 156.0 & 155.0 & 129.0 & 133.3 & $2,022.4$ \\
\hline
\end{tabular}

1 "Weather Statistics". National Environment Agency. http://app2.nea.gov.sg/weather_statistics.aspx. Retrieved 10 June 2011. 
species found on the Island of Singapore. Unfortunately, many of the natural habitats and the native orchids which thrived there have disappeared due to habitat destruction. A comparison of the habitats on the Island 150 years ago and today show that most of the mangroves and areas with freshwater wetlands have been replaced by industrial estates or residential areas. Forest and mangrove areas such as those at Choa Chu Kang, Jurong, Ang Mo Kio and Serangoon, where native orchids used to thrive, no longer exist. As a result, the native orchids are seriously endangered.

The latest conservation status of the country's native orchids can be found in the Singapore Red Data Book published in 2008 (Davison et al. 2008). Some 226 species of native orchids have been recorded in Singapore. Of these, 178 are considered to be extinct, 40 are critically endangered, one is endangered (Bulbophyllum vaginatum Rchb.f.) and two are vulnerable (Vanilla griffithii Rchb.f., Bulbophyllum trifolium Ridl.). Only five of the native orchids in the Garden City are considered to be common. Four of them are terrestrial (Arundina gramminifolia (D. Don) Hochr., Bromheadia finlaysonianum (Lindl.) Miq., Eulophia graminea Lindl., and Spathoglottis plicata Bl.), the most common of all is the epiphyte Dendrobium crumenatum Swartz, also known as the pigeon orchid.

The orchid conservation programme, which started in 1995, aims to monitor existing species, explore ways to conserve their germplasm, and increase their number through subsequent re-introduction into appropriate habitats, including roadside trees, parks and nature areas. Propagation of native species started in the mid 1990 s and seedlings were introduced in 1999. By 2009, we succeeded in propagating and introducing five species of native orchids, namely, Grammatophyllum speciosum, Bulbophyllum vaginatum, Bulbophyllum membranaceum Teijsm. and Binn., Cymbidium finlaysonianum Lindl. and Cymbidium bicolor spp. pubescens (Lindl.) Du Puy and Cribb. From 2009 to 2012, we expanded our reintroduction effort by planting more than 6000 plants consisting of 15 species in many parts of the island.

Bulbophyllum blumei. This interesting species is quite adaptable as it can be found in both the hot, lowland areas to cooler conditions. It bears one leaf. It flowers quite freely in Singapore. The inflorescence has one to two flowers. Individual flowers are $6 \mathrm{~cm}$ across. The species distributed in West Malaysia, Singapore, Sumatra, Borneo, to the Philippines, Papua and New Guinea, the Solomon Islands and Australia (Seidenfaden and Wood 1992). It is extinct in Singapore.

Bulbophyllum medusae (Lindl.) Rchb.f. Flowers of this exotic-looking species are creamy-yellow, some varieties having purple spots on the floral parts. About 15 of them are arranged in a fan shape whorl or in a circle at the tip of the flower stalk. The lateral sepals are $12 \mathrm{~cm}$ long, which is much longer than the upper sepal. When the flowers are seen from afar, the lateral sepals look like some silk threads hanging on the tree. It can be found in Thailand, Peninsular Malaysia, Indonesia, Singapore and the Pacific Islands.
Bulbophyllum membranaceum. It is found in Malaysia, Borneo, Java, Sulawesi, Sumatra, Papua and New Guinea, Solomon Islands Fiji, Samoa, Tonga and Vanuatu (Seidenfaden and Wood 1992). It is a tropical lowland species that can be found from sea level to 450 meters. Among the smallest native orchids, it has very small flowers (ca. $6 \mathrm{~mm}$ long) that do not open completely. The upper sepal is pale yellow, whereas lateral sepals are dark red, and the petals, $1.5 \mathrm{~mm}$ long, appear translucent. There are only very few naturally occurring populations of $B$. membranaceum left in Singapore. It is an epiphyte but in a particular location in the nature reserve, it grows as a lithophyte creeping on a large piece of granite.

Bulbophyllum purpurascens (T. and B.) J.J.Sm. This warm to cool growing epiphyte can be found growing in lowland and lower montane forests. It is distributed in Peninsula Malaysia, Thailand, Burma, Java, Borneo and Sumatra. The ovoid pseudobulbs bears one leathery leaf. Each inflorescence carries an umbel of 10 to 19 pale yellow flowers.

Bulbophyllum vaginatum. Bulbophyllum is the second largest orchid genus in Singapore. Species of this genus are divided into many sections. B. vaginatum, which belongs to the section Cirrhopetalum is one of the most unusual. Very often, plants grow on the branches of rain trees and Eugenia grandis. They usually cover an extensive area of a branch, and produce a spectacular sight when in full bloom. The flowers are creamy-yellow. About 15 of them are arranged in a fan-shaped whorl or in a circle at the tip of the scape. The lateral sepals are $7 \mathrm{~cm}$ long, which is many times longer than the upper sepal. The species is distributed in Thailand, Peninsular Malaysia, Singapore, Borneo and Indonesia (Seidenfaden and Wood 1992). B. vaginatum is classified as an endangered species in Singapore.

Coelogyne mayeriana Rchb.f. Characterised by the attractive, clear, apple-green petals and sepals, the lip of the flowers is conspicuously marked with dark red-brown, almost black venations. Because the dark brown-red markings are so intense in some cultivars, the name 'Black Orchid' has been given to them. Unfortunately, the flowers of this beautiful species only last for a few days. It can be found in Thailand, Peninsular Malaysia, Borneo and Indonesia (Seidenfaden and Wood 1992).

Coelogyne rochussenii De Vr. Coelogyne rochussenii has rather close narrowly conical, ribbed pseudobulbs that bear two ovate leaves, measuring $20-28 \mathrm{~cm}$ long and $10-15 \mathrm{~cm}$ wide. The pendulous inflorescence can reach up to $70 \mathrm{~cm}$ long, bearing some 30 flowers. Each flower is about $5 \mathrm{~cm}$ across, with pale yellow green sepals and petals. Side-lobes of the labellum are dark- to light-brown with whitish veins on the inside. It can be found in Thailand, Peninsular Malaysia, Sumatra, Java, Borneo, the Philippines and Sulawesi, with large altitudinal amplitude ranging from sea level to $1500 \mathrm{~m}$ (Seidenfaden and Wood 1992).

Cymbidium bicolor spp. pubescens. There is only one know naturally occurring plant of Cymbidium bicolor sp. 
pubescens in Singapore. Thought to be extinct, it was rediscovered some 10 years ago, growing on a mangrove tree, Buta Buta (Exoecaria agallocha), at the Sungei Buloh Wetland Reserve. It was last collected in Sungei Buloh in 1891 by Mr H. N. Ridley It is amazing that the species has miraculously survived much habitat loss. Leaves of the species are about $45 \mathrm{~cm}$ long, $1.5 \mathrm{~cm}$ wide, wide arching, not drooping in habit, leaf bases persistent, enclosing pseudobulbs within; raceme pendulous to $25 \mathrm{~cm}$ long; sepals and petals with broad dark purple central band, edges pale green, less than $2 \mathrm{~cm}$ long, $0.5 \mathrm{~cm}$ wide; lip yellowish with purple-brown spots; column dark purple, tip pale yellow with purple spots. The species is distributed in Malay peninsula, Singapore, Sumatra, Java and Borneo (Seidenfaden and Wood 1992). Plants can be found on trees in exposed places near the sea.

Cymbidium finlaysonianum. This species can still be found occasionally inside the nature reserve and the catchment areas. It is interesting that it can also be found growing naturally on roadside trees near suburban areas as well. Perhaps seeds were blown there from plants growing at the nearby nature areas. Cymbidium finlaysonianum grows around tree trunks and its leaves are arranged in such a way that a basket is formed. As a result, leaf litter falling from the canopy is trapped in the basket. This enables the plant to obtain nutrients from the decaying litter trapped around the roots. Such an adaptive feature is important for the survival of the plant in a nutrient-deficient environment. The species bears $90 \mathrm{~cm}$ long inflorescences. Individual flowers are $4 \mathrm{~cm}$ across. Sepals and petals are yellow-green with a brown central band. They are accompanied by a purplish lip with some yellow markings. It is distributed in Indochina, Thailand, Peninsular Malaysia, Singapore, Borneo, Indonesia and the Philippines (Seidenfaden and Wood 1992). C. finlaysonianum as critically endangered in Singapore.

Dendrobium aloifolium (Blume) Rchb.f. The flattened and pendulous stems of this epiphyte are $40-60 \mathrm{~cm}$ long. The bottom part of the stem bears flattened leaves that are $25 \mathrm{~mm}$ long and $7 \mathrm{~mm}$ in width, overlapping each other. The upper portion of the stem is covered only by sheathing leaves, and usually bears the flowers. Flowers are white, about $4 \mathrm{~mm}$ long and wide. It can be found in Thailand, Peninsular Malaysia, Borneo, Indonesia and the Philippines, growing under wet and bright areas in lowland forests.

Dendrobium leonis. Leaves of this interesting species are thick, fleshy and laterally flattened. Each of the yellowish-green flowers is borne near the apex of the stems. The flowers measure $1.5 \mathrm{~cm}$ across, and have an extremely sweet vanilla fragrance which can be detected from a distance. It is distributed throughout Indochina, China, Peninsular Malaysia, Singapore, Indonesia and Borneo (Seidenfaden and Wood 1992). The species is extinct in Singapore.

Grammatophyllum speciosum. Although Singapore is a small country, it is the home of the largest orchid plant in the world, G. speciosum. Also known as the tiger orchid, because of the markings on the flowers that resemble the skin of a tiger, it is extremely rare if not already extinct in the wild in Singapore. However, it can still be found in Indochina, Peninsular Malaysia, Thailand, Borneo, Indonesia, the Philippines and the Pacific Islands (Seidenfaden and Wood 1992). G. speciosum was last found in the wild in Tuas and Pulau Ubin. Since a mature plant could weigh more than a ton, it is a wonder that such a huge plant could live on the trunk of a tree. G. speciosum is nationally extinct.

Phalaenopsis cornu cervi (Breda) Bl. and Rchb.f. This attractive species bears many sprays displaying numerous star-shaped, long-lasting flowers. Individual flowers measure $3 \mathrm{~cm}$ across. Several colour forms occur in nature, ranging from dark cinnamon-red, either banded or blotched, to yellow and pale green. It can be found in India, Burma, Indochina, Peninsular Malaysia, Borneo, Indonesia and the Philippines.

Thrixspermum amplexicaule. Most Thrixspermum species are epiphytes. However, Thrixspermum amplexicaule is different, it grows in a semi-aquatic environment. The lower half of the plant grows submerged in water. It grows near fresh water bodies such as fresh water swamps or back mangrove areas. The flowers are attractive, pale lilac in colour and about $3 \mathrm{~cm}$ across. There are only a few populations left on the island. Flowers of this critically endangered species only last for one day

Vanilla griffithii Rchb.f. Vanilla is one of the most widely distributed orchid genera in the world. It consists of about 100 species distributed throughout the tropics. Vanilla species are climbers. In Singapore, the genus is represented by Vanilla griffithii. The leaves are fleshy, rather variable in size, from 10 to $16 \mathrm{~cm}$ long and 4 to $8 \mathrm{~cm}$ wide. The species flowers occasionally. The petals and sepals are white, flushed with pale green, of 2.5 to $3 \mathrm{~cm}$ long, and 1.4 to $1.5 \mathrm{~cm}$ wide. The lip is white with a pale yellow tip, and is hairy in the middle. It can be found in Anambas Islands, Karimun Besar Island, Sumatra and Borneo and Peninsular Malaysia.

\section{Materials and methods}

The method of propagation for the various species is shown in Table 2 . The following species were purchased from local nursery for trial planting, seedlings will also be raised from nursery plants: Bulbophyllum purpurescens, Coelogyne mayeriana, Coelogyne rochussenii, Dendrobium aloifolium and Phalaenopsis cornu cervi.

\section{Pollination}

The most effective way to conserve species is to propagate them through seeds by sexual reproduction. Natural pollinations occurred in B. membranaceum, B. vaginatum, C. bicolor spp. pubescens, C. finlaysonianum, and T. amplexicaule. For B. blumei, B. medusa, D. leonis, cross 
Table 2 Method of propagation.

\begin{tabular}{|c|l|l|l|}
\hline No. & Species & Propagation material & Origin of propagation material \\
\hline 1 & Bulbophyllum blumei & Seeds from outcrossing & Nursery \\
\hline 2 & Bulbophyllum medusae & Seeds from outcrossing & Nursery \\
\hline 3 & Bulbophyllum membranaceum & Seeds from natural population & Native plants \\
\hline 4 & Bulbophyllum vaginatum & Seeds from natural population & Native plants \\
\hline 5 & Cymbidium bicolor subsp. pubescens & Seeds from natural population & Native plants \\
\hline 6 & Cymbidium finlaysonianum & Seeds from natural population & Native plants \\
\hline 7 & Dendrobium leonis & Seeds from outcrossing & Nursery \\
\hline 8 & Grammatophyllum speciosum & Seeds from selfing & Nursery \\
\hline 9 & Thrixspermum amplexicaule & Seeds from natural population & Native plants \\
\hline 10 & Vanilla girffithii & Cuttings from natural population & Native plants \\
\hline
\end{tabular}

pollinatios were carried out in the nursery. Self pollination was carried out for G. speciosum.

\section{Harvesting of seed capsules}

Seed capsules were collected from native population of B. membranaceum, B. vaginatum, C. bicolor subsp. pubescens, C. finlaysonianum and T. amplexicaule. For B. blumei, B. medusae, D. leonis and G. speciosum, capsules were collected from nursery plants after artificial pollinations. The best time to collect the capsules is when they begin to turn yellow, but without splitting open.

\section{Surface sterilisation of capsules}

The capsules were scrubbed with a toothbrush under running water and a household detergent and they were rinsed well. After dipping in $70 \%$ ethyl alcohol for one minute, the capsules were dipped in 20\% Chlorox for 30 minutes before being rinsed thoroughly with sterile distilled water. The capsules were split to remove the seeds.

\section{Preparation of media}

A modified Knudson C medium (Table 3) was prepared for the germination of seeds. Seedlings were transferred to a second medium (Table 3). Chemical components and organic additives of the medium were added to water (following the instruction in Arditti et al. 1982). The mixture was heated with stirring to dissolve the agar and $50 \mathrm{ml}$ of medium was dispensed into $250 \mathrm{ml}$ culture flasks. All media were sterilized by heating in an autoclave to $121^{\circ} \mathrm{C}$ at $1.06 \mathrm{~kg} \mathrm{~cm}^{-2}$ for 20 minutes.

\section{Sowing the seeds}

For all the species listed in Table 2, seeds were scraped from inside the fruit and a small amount was spread on the agar surface in each flask. Most tropical seeds, especially those of epiphytes, can be germinated on a sterile
Table 3 Modified Knudson C media for orchid seed germination.

\begin{tabular}{|c|c|c|c|}
\hline \multicolumn{4}{|c|}{ Amount per liter of culture medium, $\mathbf{m g}^{\mathrm{a}}$} \\
\hline No. & Component & $\begin{array}{c}\text { Seed } \\
\text { germination }\end{array}$ & Seedlings \\
\hline & Macroelements & & \\
\hline 1 & Ammonium sulfate, $\left(\mathrm{NH}_{4}\right)_{2} \mathrm{SO}_{4}$ & 500 & 500 \\
\hline 2 & $\begin{array}{l}\text { Calcium nitrate, } \\
\left.\mathrm{Ca}\left(\mathrm{NO}_{3}\right)_{2} \cdot 4 \mathrm{H}_{2}\right) \\
\end{array}$ & 1000 & 1000 \\
\hline 3 & \begin{tabular}{|l} 
Manganese sulfate, \\
$\mathrm{MnSO}_{4} \cdot 4 \mathrm{H} 2 \mathrm{O}$ \\
\end{tabular} & 7.5 & 7.5 \\
\hline 4 & $\begin{array}{l}\text { Magnesium sulfate, } \\
\mathrm{MgSO}_{4} \cdot 7 \mathrm{H}_{2} \mathrm{O}\end{array}$ & 250 & 250 \\
\hline 5 & Potassium phosphate, $\mathrm{KH}_{2} \mathrm{PO}_{4}$ & 250 & 250 \\
\hline 6 & Chelated iron & & \\
\hline (a) & Chelating agent, $\mathrm{Na}_{2}$ EDTA & 37.3 & 37.3 \\
\hline (b) & Iron sulfate, $\mathrm{FeSO}_{4} \cdot 7 \mathrm{H}_{2} \mathrm{O}$ & 27.8 & 27.8 \\
\hline 7 & Microelements & & \\
\hline (a) & Boric acid, $\mathrm{H}_{3} \mathrm{BO}_{3}$ & 6.2 & 6.2 \\
\hline (b) & Cobalt chloride $\mathrm{CoCl}_{2} \cdot 6 \mathrm{H}_{2} \mathrm{O}$ & 0.025 & 0.025 \\
\hline (c) & Copper sulfate, $\mathrm{CuSO}_{4} \cdot 5 \mathrm{H}_{2} \mathrm{O}$ & 0.025 & 0.025 \\
\hline (d) & $\begin{array}{l}\text { Manganese sulfate, } \\
\mathrm{MnSO}_{4} \cdot 4 \mathrm{H}_{2} \mathrm{O} \\
\end{array}$ & 22.3 & 22.3 \\
\hline (e) & Potassium iodide, $\mathrm{KI}$ & 0.83 & \\
\hline (f) & $\begin{array}{l}\text { Sodium molybdate, } \\
\mathrm{Na}_{2} \mathrm{MoO}_{4} \cdot 2 \mathrm{H}_{2} \mathrm{O}\end{array}$ & 0.25 & 0.25 \\
\hline \multirow[t]{2}{*}{ (g) } & Zinc sulfate, $\mathrm{ZnSO}_{4} \cdot 4 \mathrm{H}_{2} \mathrm{O}$ & 8.6 & 8.6 \\
\hline & Sugar & & \\
\hline \multirow[t]{2}{*}{8} & Sucrose & $20 \mathrm{~g}$ & $10 \mathrm{~g}$ \\
\hline & Complex additive & & \\
\hline 9 & Ripe banana & & $100 \mathrm{~g}$ \\
\hline \multirow[t]{2}{*}{10} & Potato & & $100 \mathrm{~g}$ \\
\hline & Darkening agent & & \\
\hline \multirow[t]{2}{*}{11} & Vegetable charcoal & $2 \mathrm{~g}$ & $2 \mathrm{~g}$ \\
\hline & Solvent & & \\
\hline \multirow[t]{2}{*}{12} & Distilled water & to $1000 \mathrm{ml}$ & to $1000 \mathrm{ml}$ \\
\hline & Solidifier & & \\
\hline \multirow[t]{2}{*}{13} & Agar & $12 \mathrm{~g}$ & $12 \mathrm{~g}$ \\
\hline & $\mathrm{pH}$ & 5.6 & 5.6 \\
\hline
\end{tabular}

aAmounts are given in $\mathrm{mg}$ unless indicated otherwise. 
nutrient medium (such as modified Knudson C, Table 3; Knudson 1946; Arditti et al. 1982; Yam and Weatherhead 1988).

\section{Maintaining the cultures}

Flasks which contain seeds should be maintained at $25 \pm 1{ }^{\circ} \mathrm{C}$ about $30-50 \mathrm{~cm}$ below two plant growth fluorescent tubes. Seedlings were subcultured twice in a second medium (Table 3), and grown in the laboratory for 12 months before being transplanted into flasks.

\section{Planting of seedlings in nursery}

About 30 seedlings were planted into community pots, using small charcoal and brick chips as media. For Bulbophyllum blumei, Bulbophyllum medusae, Bulbophyllum membranaceum, Bulbophyllum vaginatum, and Dendrobium leonis, when seedlings become established, 10 seedlings were planted per fern bark or coconut husk measuring $7 \mathrm{~cm}$ long by $5 \mathrm{~cm}$ wide. They were grown at the nursery for six months until new shoots began to emerge before reintroduction. For Cymbidium bicolor spp. pubescens and Cymbidium finlaysonianum, one seedling was planted on each fern bark, plants were grown at the nursery for 12 to 18 months. Plants were ready for reintroduction when each seedling had three to four new shoots and a healthy root system. For Thrixspermum amplexicaule, seedlings are grown in soil composed of $30 \%$ top soil, $30 \%$ sand, $20 \%$ compost and $10 \%$ charcoal chips. Three seedlings are tied to a bamboo pole about $30 \mathrm{~cm}$ long with horticultural wires. In the case of $V$. griffithii, seeds collected from natural population did not germinate, therefore the species was propagated vegetaively by stem cuttings. Stem cuttings with three to four internodes were removed from natural population at Pualu Ubin. Leaf was removed from the last node of the cutting, the node was inserted into the soil mix for T. amplexicaule. One to two cutting can be planted in a 4 inch pot. Since $V$. griffithii is a climber, the stem cuttings were suppoted by a $2 \mathrm{~cm}$ square wooden stick.

\section{Reintroduction}

All the epiphytic species (B. blumei, B. medusae, B. membranaceum, B. purpurascens, B. vaginatum, C. mayeriana, C. rochussenii, C. bicolor spp. pubescens, C. finlaysonianum, D. aloifolium, D. leonis, G. speciosum, P. cornu cervi) were planted on trees. It is very important that the seedlings be planted under the right environmental conditions on the right tree. First, suitable host trees were selected using the following criteria: 1 . the surrounding area of the host tree should have high relative humidity, 2. host trees should have some epiphytes growing on them because if the conditions are suitable for other epiphytes, it is likely that they should also be good for epiphytic orchids too (some of the roadside trees that are suitable for epiphytes are: rain tree (Samanea saman), Acacia (Acacia auriculiformis), Mahogany (Swietenia macrophylla), the Madras Thorn (Pithecellobium dulce), yellow Flame (Peltophorum pterocarpum) and Angsana (Pterocarpus indicus)), 3. when a suitable tree was selected, fern barks with established seedlings were secured on the tree trunk by horticultural wires or nails, 4 . seedlings were planted in partially shady area, with at least 50\% shade to avoid being scorched. The best time for planting is before or during the rainy season. For Thrixspermum amplexicaule, locations for reintroduction must have a body of fresh water, such as the edge of pond. Other aquatic plants are needed to provide shelter and support for the young plants; examples are mangrove ferns (Acrostichum aureum and Acrostichum speciosum) and Papyrus (Cyperus papyrus). To carry out planting, bamboo poles with three seedlings attached are removed from the pots with no soil attached. The bamboo is inserted into the soil near the base of support plants. The base of seedlings should be submerged in water after planting. The best time to plant is during the rainy season, from mid October to December. With plenty of water supply, new roots emerge and the seedlings establish quickly in their new home. In Singapore, the rainy season starts around October and last until January (Table 1), planting is usually done in early October.

\section{Areas of reintroduction}

Different native species were reintroduced to various locations as indicated in Fig. 1 and Table 4.

Several experiments were carried out to find out the best criteria for reintroduction:

\section{Experiments to test the effect of microclimate to the survival rate of the seedlings of $C$. bicolor spp. pubescens}

The experiment was carried out at Sungei Buloh Wetland Reserve in 2008. Twenty seedlings each were planted near the visitor centre and the mangrove area respectively. Area near the visitor centre was more sheltered, it had less direct sunlight, the trees had more epiphytes. The mangrove area was near the sea and therefore more exposed, the trees were without any epiphytes. Survival rate of seedlings were monitored for one year after planting.

\section{Experiments to test the effect of seedling size and survival rate of $G$. speciosum}

Seedlings of different sizes were planted to see if size of seedlings had any effect on their survival rate. Smaller seedlings were 26 months old and about $15-20 \mathrm{~cm}$ tall with 5-6 leaves, they were planted in 1999 at the Botanic Gardens, Bukit Timah Nature Reserve, Orchard Boulevard and Pulau Ubin. Larger seedlings of about $30-40 \mathrm{~cm}$ tall with 16-20 leaves were planted at the same sites in 2001. Survival rate was monitored for two years after planting. 


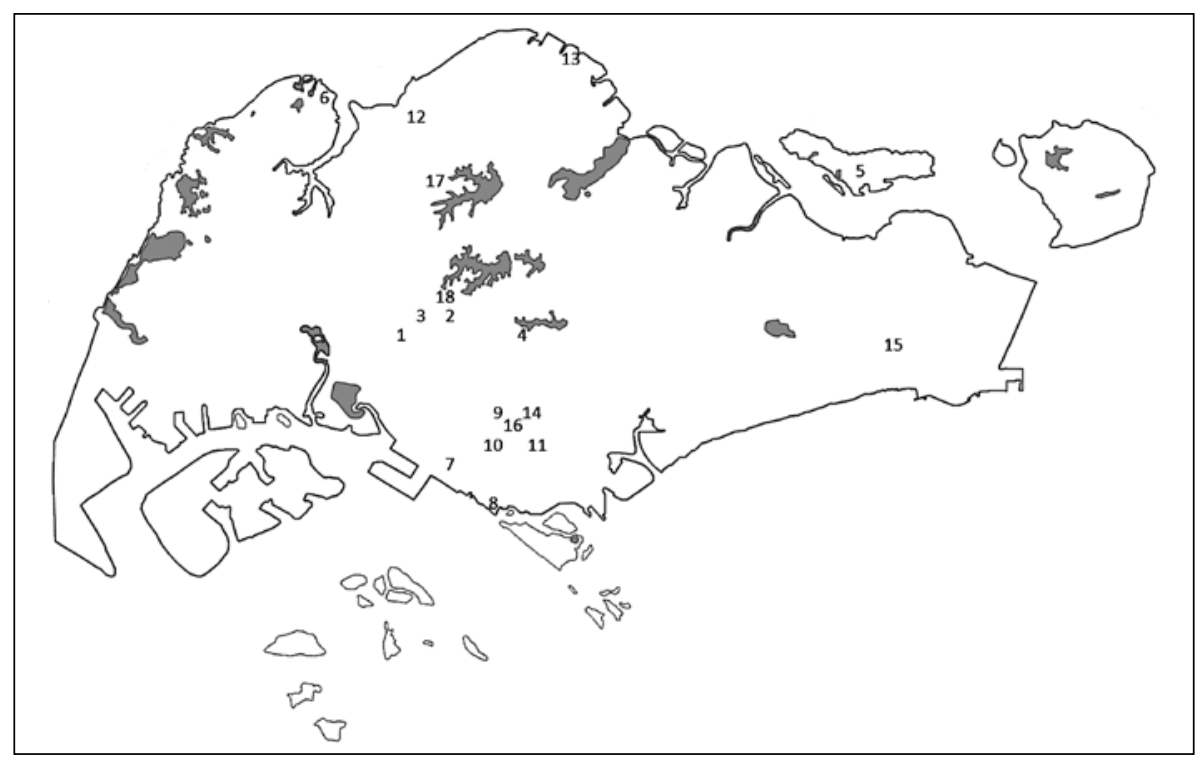

Fig. 1 Areas of reintroduction. 1 - Bukit Batok Nature Park; 2 - Bukit Timah Nature Reserve; 3 - Dairy Farm Visitors Centre; 4 - MacRitchie Reservoir; 5 - Pulau Ubin; 6 - Sungei Buloh; 7 - Kentridge Park; 8 - Labrador Park; 9 - Singapore Botanic Gardens; 10 - Telok Blangah Hill Park; 11 - Tiong Bahru Park; 12 - Woodland Town Garden; 13 - Sembawang Park; 14 - Cluny Road; 15 - East Coast Parkway; 16 - Holland Road/ Napier Road; 17 - Mandai Road; 18 - Singapore Quarry.

Table 4 Survival and growth of native orchids, two years or more after reintroduction at various locations in Singapore.

\begin{tabular}{|c|c|c|c|c|c|c|c|c|c|}
\hline $\begin{array}{l}\text { Loc. } \\
\text { on } \\
\text { map }\end{array}$ & Area & $\begin{array}{l}\text { Bulbo- } \\
\text { phyllum } \\
\text { blumei }\end{array}$ & $\begin{array}{c}\text { Bulbophyllum } \\
\text { membra- } \\
\text { naceum }\end{array}$ & $\begin{array}{c}\text { Bulbo- } \\
\text { phyllum } \\
\text { vaginatum }\end{array}$ & $\begin{array}{l}\text { Cymbidium } \\
\text { bicolor spp. } \\
\text { pubescens }\end{array}$ & $\begin{array}{c}\text { Cymbidium } \\
\text { finlayso- } \\
\text { nianum }\end{array}$ & $\begin{array}{l}\text { Dendro- } \\
\text { bium } \\
\text { leonis }\end{array}$ & $\begin{array}{c}\text { Grammato- } \\
\text { phyllum } \\
\text { speciosum }\end{array}$ & $\begin{array}{l}\text { Thrixsper- } \\
\text { mum ample- } \\
\text { xicaule }\end{array}$ \\
\hline 1 & $\begin{array}{l}\text { Bukit Batok } \\
\text { Nature Park }\end{array}$ & & & & & & $\S$ & $\S$ & \\
\hline 2 & $\begin{array}{l}\text { Bukit Timah } \\
\text { Nature Reserve }^{a}\end{array}$ & & & & & & & $\S$ & \\
\hline 3 & $\begin{array}{l}\text { Dairy Farm } \\
\text { Visitors Centre }^{a}\end{array}$ & & $\S$ & $\S$ & $\S$ & & & & \\
\hline 4 & $\begin{array}{l}\text { MacRitchie } \\
\text { Reservoira }^{\text {Rese }}\end{array}$ & $\S$ & & $\S$ & $\S$ & & & & $\S$ \\
\hline 5 & Pulau Ubin ${ }^{a}$ & & $\S$ & $\S$ & $\S$ & $\S$ & & $\S$ & ** \\
\hline 6 & Sungei Buloh ${ }^{a}$ & & $\S$ & & ** & & & $\S$ & \\
\hline 7 & Kentridge Park ${ }^{b}$ & & ** & * & & ** & & $\#$ & \\
\hline 8 & Labrador Park ${ }^{b}$ & & & & & & $\S$ & $\S$ & \\
\hline 9 & $\begin{array}{l}\text { Singapore } \\
\text { Botanic Gardens }\end{array}$ & $\S$ & $\S$ & $\S$ & $\S$ & $\S$ & & $\S$ & \\
\hline 10 & $\begin{array}{l}\text { Telok Blangah } \\
\text { Hill Park }^{\mathrm{b}}\end{array}$ & & & $\S$ & $\S$ & $\S$ & & $\S$ & \\
\hline 11 & Tiong Bahru Park & & $\S$ & $\S$ & & & & $\S$ & \\
\hline 12 & $\begin{array}{l}\text { Woodland Town } \\
\text { Garden }^{b}\end{array}$ & & $\S$ & $\S$ & & & & $\S$ & \\
\hline 13 & $\begin{array}{l}\text { Sembawang } \\
\text { Park }^{\text {b }}\end{array}$ & & & $\S$ & & ** & & $\S$ & \\
\hline 14 & Cluny Roadc & & $\S$ & & & & & $\#$ & \\
\hline 15 & $\begin{array}{l}\text { East Coast } \\
\text { Parkwayc }\end{array}$ & & & $\S$ & & $\S$ & & $\S$ & \\
\hline 16 & $\begin{array}{l}\text { Holland Road } \\
\text { Napier Roadc }\end{array}$ & $\S$ & $\S$ & $\S$ & $\S$ & $\S$ & $\S$ & $\S$ & \\
\hline 17 & Mandai Roadc & & & $\S$ & & & & $\S$ & \\
\hline 18 & $\begin{array}{l}\text { Singapore } \\
\text { Quarry }^{d}\end{array}$ & & & & & & & & $* *$ \\
\hline
\end{tabular}

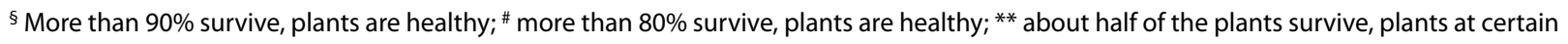
locations are growing better than the others; * only some plants in certain locations survive.

a Nature areas, mostly secondary forests; ${ }^{b}$ Parks; ${ }^{c}$ Roadside; ${ }^{d}$ Pond. 


\section{Experiments to test the effects of host tree species to survival rate of $G$. speciosum}

Seedlings of G. speciosum $(15-20 \mathrm{~cm}$ tall with 5-6 leaves) were affixed onto Durio kutejensis (durian), Nephelium lappaceum (rambutan), Mangifera indica (mango), Pterocarpus indicus (Angsana), Fagraea fragrans (Tembusu) and Samanea saman (rain trees). Their survival rate was monitored for two years after planting.

\section{Results}

The following species have been successfully reintroduced for 2 to 10 years and all of the re-introductions are growing well (Table 4): Bulbophyllum blumei, Bulbophyllum membranaceum, Bulbophyllum vaginatum, Cymbidium finlaysonianum, Dendrobium leonis, Grammatophyllum speciosum, Cymbidium bicolor spp. pubescens, and Thrixspermum amplexicaule. Species that are planted for less than two years are still being monitored and therefore are not reported here.

Bubophyllum blumei. We started the reintroduction in 2009. They were affixed onto Pterocarpus indicus (Angsana), and Samanea saman (rain trees). Those planted at the Singapore Botanic Gardens, Holland Road and MacRitchie Reservoir are doing very well. MacRitchie Reservoir is the most suitable location (Table 4). The plants there grow vigorously and they have been flowering regularly. More seedlings have been planted recently at East Coast Parkway near Changi Airport, Labrador Park, East Coast Park, West Coast Park and Pasir Ris Park.

Bulbophyllum membranaceum. Seedlings were planted in the Singapore Botanic Gardens, Woodlands Town Garden, Dairy Farm Visitors Centre, Pulau Ubin, Holland Road, Cluny Road, Tiong Bahru Park, Kentridge Park and Sungei Buloh. They were affixed onto Pterocarpus indicus (Angsana), and Samanea saman (rain trees). B. membranaceum is a lithophyte, it thrives well under a wide range of condition. After six years, more than $80 \%$ of the reintroduced plants survive (Table 4). They produced new shoots and their roots have grown onto the bark of the host tree. Some reintroduced plants have flowered and seed capsules were observed to form naturally.

Bulbophyllum vaginatum. Seedlings of B. vaginatum have been reintroduced to areas shown in Table 4. They are: Singapore Botanic Gardens, Pulau Ubin, Tiong Bahru Park, Mandai Road, Kentridge Park, Sembawang Park, Woodland Town Garden, Telok Blangah Hill Park, Cluny Road, Dairy Farm Visitors Centre and Holland Road. The seedlings were affixed onto Pterocarpus indicus (Angsana), Fagraea fragrans (Tembusu) and Samanea saman (rain trees). More than $80 \%$ of the re-introduced plants survived in the Singapore Botanic Gardens, Pulau Ubin, Tiong Bahru Park, Mandai Road, Sembawang Park, Woodland Town Garden, Telok Blangah Hill Park, Cluny Road, Dairy Farm Visitors Centre. All of the surviving seedlings have produced new shoots and their roots have grown onto the bark of the host tree. Many re-introduced plants have flowered. Most seedlings planted at Kent Ridge Park did not survive (Table 4), this is because the major tree species Fagraea fragrans (Tembusu), has a very dry bark which does not support the growth of epiphytes.

Cymbidium bicolor spp. pubescens. Seedlings were reintroduced first to Sungei Buloh in 2007. Other plants were subsequently planted at the Singapore Botanic Gardens, Telok Blangah Hill Park, Dairy Farm Visitors Centre, Sungei Buloh, MacRitchie Reservoir, Pulau Ubin, Holland Road and Napier Road. More than $90 \%$ of the seedlings have done well in most areas. An exception is those planted at exposed area on young mangrove trees at Sungei Buloh (Table 4), more than $90 \%$ of the seedlings dehydrated and died; on the other hand $100 \%$ of the seedlings planted on trees near the visitor centre (less direct sunlight, the trees had more epiphytes) survived. Some of the seedlings planted on a rain tree outside the Dairy Farm Visitors Centre flowered in May 2009 and March 2010 respectively. Seed capsules were collected in March 2010 and the seeds germinated in the laboratory.

Cymbidium finlaysonianum. We started reintroducing Cymbidium finlaysonianum in 2002 The seedlings planted have been growing for 2-8 years at the various locations as shown in Table 4 (Singapore Botanic Gardens, Pulau Ubin, Tiong Bahru Park, Mandai Road, Kentridge Park, Sembawang Park, Woodland Town Garden, Telok Blangah Hill Park, Cluny Road, Dairy Farm Visitors Centre and Holland Road). More than $80 \%$ of the re-introductions are growing well. New shoots have developed and roots are firmly established on tree trunks. Many of the plants have flowered and fruited.

Dendrobium leonis. Reintroduction work started in 2009. They were affixed onto Pterocarpus indicus (Angsana), and Samanea saman (rain trees). So far, those planted at Bukit Batok Nature Park, Labrador Park and Holland Road are doing very well (Table 4) and all of them have flowered. This species can thrive under a wide range of environmental condition, from shady areas to direct morning sun. Perhaps the fleshy leaves of the species enable the species to withstand drought and sunny conditions. More seedlings have also been planted at East Coast Parkway near Changi Airport, Labrador Park, East Coast Park, West Coast Park and Pasir Ris Park.

Grammatophyllum speciosum. Seedlings planted have been growing for 2-10 years at the various locations (Singapore Botanic Gardens, Pulau Ubin, Bukit Batok Nature Park, Bukit Timah Nature Reserve (BTNR), Fort Canning, Labrador Park, Orchard Boulevard, Holland Rd, Tiong Bahru Park, Mandai Road, Kentridge Park, Sembawang Park, Woodland Town Garden, Telok Blangah Hill Park, Cluny Road, Sungei Buloh, Mount Faber, East Coast Park, West Coast Park and Kim Seng Park). More than 80\% are doing well (Table 4). New shoots have developed and roots are firmly established on tree trunks. Unfortunately, 
Table 5 Survival of re-introduced seedlings of Grammatophyllum speciosum in various parts of Singapore.

\begin{tabular}{|l|l|c|c|c|}
\hline Location & Host tree & Seedling size (cm) & Number of seedlings & Survival rate (\%) \\
\hline \multirow{2}{*}{ Botanic Gardens } & Samanea saman & $15-20$ & 20 & 10 \\
& & $30-40$ & 20 & 70 \\
\hline Bukit Batok Nature Park & Samanea saman & $30-40$ & 20 & 90 \\
\hline \multirow{2}{*}{ Bukit Timah Nature Reserve } & Samanea saman & $15-20$ & 20 & 10 \\
& & $30-40$ & 20 & 75 \\
\hline \multirow{2}{*}{ Holland Road } & Samanea saman & $30-40$ & 40 & 95 \\
\hline \multirow{3}{*}{ Orchard Boulevard } & \multirow{3}{*}{ Samanea saman } & $80-100$ & 80 & 90 \\
\hline & & $15-20$ & 20 & 45 \\
& Durio kutejensis & $30-40$ & 20 & 90 \\
\hline & Nephelium lappaceum & $15-20$ & 4 & 25 \\
& Mangifera indica & $15-20$ & 4 & 25 \\
& Pterocarpus indicus & $15-20$ & 4 & 25 \\
& Fagraea fragrans & $15-20$ & 10 & 50 \\
& & $15-20$ & 10 & 20 \\
\hline Tiong Bahru Park & Samanea saman & $30-40$ & 20 & 35 \\
\hline Upper Pierce Reservoir & Samanea saman & $30-40$ & 20 & 90 \\
\hline
\end{tabular}

most seedlings planted outside the BTNR Visitors Centre were damaged or removed by animals, probably squirrels and monkeys. Two plants that managed to survived are doing extremely well, with healthy and strong stems. We also learned that larger plants (with at least 5 shoots, with some 25 leaves reaching a length of $45 \mathrm{~cm}$ ) survive better and can establish faster than smaller plants (Table 5). Pterocarpus indicus and Samanea saman were better host trees than Durio kutejensis, Nephelium lappaceum, Mangifera indica, and Fagraea fragrans (Table 5).

Thrixspermum amplexicaule. More than $80 \%$ of the reintroduced plants are able to survive at MacRitchie Reservoir (Table 4). Some seedlings planted there were attacked by herbivors, fortunately new shoots were observed to emerge from lower nodes of the damaged plants. Less than half of the seedlings planted in Pulau Ubin and Singapore Quarry surived. The ponds where the seedlings were planted tend to dry up during the dry season and water level can rise substantially during the rainy season. The low survival rate may due to the fluctuation in the environmental conditions.

After observing the reintroduced plants for two to ten years, we have a better understanding of the species and the microclimate they prefer. In 2009, the National Parks Board decided to enlarge the planting effort and plan to plant some 6000 plants all over the island, from 2009 to 2012. Before 2009, all the plants were propagated from seeds. From end of 2009 onwards, because of the large number of plants required for the reintroduction, some plants were purchased from local nurseries to supplement those propagated from seeds by the laboratory. The following newly reintroduced species are healthy and showing signs of active growth: B. medusae, B. purpurascens, C. mayeriana, C. rochussenii, D. aloifolium and P. cornu cervi. Their growth will continue to be monitored.

\section{Effect of microclimate to the survival rate of C. bicolor spp. pubescens}

At Sungei Buloh Wetland Reserve, all the twenty seedlings planted near the visitor centre survived, only 2 seedlings planted near the mangrove area thrived one year after planting.

\section{Effect of seedling size and survival rate of G. speciosum}

Smaller seedlings ( 26 months old and about $15-20 \mathrm{~cm}$ tall with 5-6 leaves) had a much lower survival rate than larger seedlings (50 months old about $30-40 \mathrm{~cm}$ tall with 16-20 leaves) two years after planting (Table 5).

\section{Effects of host tree species to survival rate of G. speciosum}

Two years after planting, seedlings of G. speciosum had the highest survival rate on Pterocarpus indicus and $\mathrm{Sa}$ manea saman. Only 10\% seedlings survived on Fagraea fragrans (Table 5).

\section{Discussion}

We have learnt that the following points are important to ensure successful reintroduction.

\section{Microclimate of the area such as relative humidity}

Seedlings planted in areas with high relative humidity tend to survive better than those in dry areas. For example, among all the planting locations, Kent Ridge Park is located at the highest elevation with the most exposed environment. Seedlings planted there had the lowest rate 
of survival (Table 4). Similarly, for seedlings of $C$. bicolor spp. pubescens planted at Sungei Buloh, those planted near the visitor centre (less exposed to direct sun light and strong wind) grew very well and had $100 \%$ survival rate; on the other hand, those planted near the exposed mangrove area, only $10 \%$ survived. In Pulau Ubin, seedlings established in a damp area inside a secondary forest are healthier and more vigorous than those growing near the sea where the breeze tends to dry the bark faster. Orchids planted at forested area such as MacRitchie Reservoir grow well without any watering even during drought periods.

\section{Host tree species and the presence of other epiphytes}

Trees that support more epiphytes tend to be better hosts than those with fewer epiphytes. Seedlings of G. speciosum had the highest survival rate on Pterocarpus indicus and Samanea saman. Only 10\% seedlings survived on Fagraea fragrans (Table 5). Both Pterocarpus indicus and Samanea saman carry have more epiphytes than Fagraea fragrans. It is observed that if conditions are suitable for other epiphytes, they are also more appropriate for epiphytic orchids too. Young trees do not have epiphytes grow on them because of the fine bark texture. When trees reach 15 to 20 years, their bark surface becomes rougher and epiphytes such as mosses and liverworts begin to appear (Tee 2009). When dead leaves from surrounding trees fall within the cracks and crevices of the old tree trunk, they decay and the resulting humus not only holds water but also provides nutrients for the epiphytes. These pockets of organic matters also create suitable habitats for the germination and subsequent development of orchid seeds dispersed by the wind. The best locations for the epiphytes to thrive are the forks of the main branches. When water flows from the top of the tree to the ground, it tends to flow towards the fork area before coming down to the ground. Therefore, the fork areas tend to accumulate more moisture and are more suitable for epiphytes to thrive. Of all the roadside trees that are suitable for epiphytes, the rain tree exhibits the most luxuriant growth of epiphytic plants. The most common epiphyte is Bird's Nest Fern (Asplenium nidus) and the most common orchid is Dendrobium crumenatum, also known as the Pigeon orchid.

\section{Size of plants}

The size of seedlings is also an important factor in determining survival. For example for G. speciosum, larger plants (with at least five shoots, with some 25 leaves reaching a length of $45 \mathrm{~cm}$ ) tend to survive better and become established faster than smaller plants (Table 5). For G. speciosum, larger plants are more mature, the pseudobulbs are longer and more fleshy, which enable the plant to withstand a longer period of drought and dehydration, that in turn would allow the plants a longer period to adapt to the conditions of their new home. For small sized species such as $B$. vaginatum and B. membranaceum, seedlings were planted on fern bark. They must be grown at the nursery for at least 6 months until new shoots and roots begin to emerge before reintroduction. Such seedlings have high rate of survival when planted under the right environmental conditions.

\section{Time of planting}

The best time for planting is before or during the rainy season. In Singapore, then rainy season starts around October and last until January. March also tends to be rather wet as well (Table 1). Therefore most of our planting were done from late September to November, planting can also be done in late February to March. Seedlings planted during these periods established themselves quickly by producing new shoots and roots. Once the roots attach themselves to the tree bark, they can absorb water and nutrients directly from the environment.

\section{Growth of reintroduced plant throughout the year}

Singapore has a tropical rainforest climate with no distinctive seasons, uniform temperature throughout the year, high relative humidity, and abundant rainfall. Temperatures usually range from 23 to $33^{\circ} \mathrm{C}$. Relative humidity averages around $80 \%$ in the morning and $73 \%$ in the afternoon. April and May are the hottest months, with the wetter monsoon season from November to January (Table 1). Reintroduced plants grow extremely well during the wet months, their pseudobulbs look very turgid and leaves are green. However, during the dry periods, leaves tend to wither, and pseudobulbs shrink. During prolonged drought, some leaves may turn yellow or even drop off. Sometimes half of the plant may look dead. Fortunately most of these plants revive when the rains start. New shoots emerge and the plants regain their former lush appearance.

\section{Maintenance}

Our aim is to have as little maintenance as possible. Orchids planted under the right microclimate should be able to thrive by themselves like other epiphytes. Therefore very little maintenance is needed. In case of severe drought, plants can be drenched twice a week. If plants are reintroduced during the dry season, or planted at more exposed locations, it is necessary to water them at least three times a week, once the roots of the newly planted orchids attach themselves to the tree trunk, watering can be reduced.

When dead leaves from trees fall within the cracks and crevices of the old tree trunk, they decay and the resulting humus not only holds water but also provide nutrients for the epiphytes. The reintroduced orchids should be able to thrive like other epiphytes without the application 
of fertilisers. In order to help the seedlings to establish faster, a light, balanced foliar fertiliser can be applied one month after planting and for a period of six months after that.

\section{Conclusion}

The reintroduced plants have grown more than eight years in various nature park areas as well as in parks and roadside trees. More than $80 \%$ of the plants survived and many of them have flowered and fruited. Our hope is that these plants will be able to self propagate by seeds. If this happens, the re-introduced species will act as catalysts in the restoration of at least part of the original ecosystem. For example, pollinators may be attracted to come back to pollinate the flowers. Orchid seeds that are formed naturally after flowers are pollinated may be blown to the proper environment where appropriate mycorrhizal fungi are present. We hope that one day, natural populations of native species will sprout up all over the island!

\section{Acknowledgements}

I (TWY) thank Joseph Arditti and Dennis Whigham for providing critical reviews on the manuscript. I thank the following divisions and departments in the National Parks Board which provided valuable assistance throughout the project: Centre for Urban Greenery and Ecology (CUGE), Coastal Parks, HortParks, Nature Conservation, Parks, Singapore Botanic Gardens and Streetscape.

\section{REFERENCES}

Arditti J, Clements MA, Fast G, Hadley G, Nishimura G, Ernst R (1982) Orchid Seed Germination and seedling culture - a manual. In: Arditti J (ed) Orchid biology: reviews and perspectives, Vol. II. Cornell University Press, Ithaca, NY, pp 243-370.

Davison GWH, Ng PKL, Ho HC (2008) The Singapore Red Data Book. Threatened Plants and Animals of Singapore. Nature Society Singapore, Singapore.

Knudson L (1946) A new nutrient solution for the germination of orchid seed. Am. Orchid Soc. Bull. 15: 214-217.

Seidenfaden G, Wood JJ (1992) The Orchids of Peninsular Malaysia and Singapore. Olsen and Olsen. Fredensborg, Denmark.

Tee, SP (2009) Trees of our garden city. National Parks Board. Singapore, pp 329-333.

Yam TW (2008) Conservation and re-introduction of the tiger orchid and other native orchids of Singapore. In Soorae PS (ed) Global Re-introduction Perspectives. Re-introduction casestudies from around the globe. IUCN/SSC Re-introduction Specialist Group, Abu Dhabi, UAE, viii + 284 pp, pp 261-265.

Yam TW, Weatherhead MA (1988) Germination and seedling development of some Hong Kong orchids. I. Lindleyana 3: 156-160. 